\title{
Commentary: Invasive mediastinal staging for patients with lung cancer-We need to do better!
}

\author{
Benjamin D. Kozower, MD, MPH
}

\author{
From the Department of Surgery, Washington University School of Medicine, St Louis, Mo. \\ Disclosures: Author has nothing to disclose with regard to commercial support. \\ Received for publication May 9, 2019; accepted for publication May 10, 2019; available ahead of print June 22, \\ 2019. \\ Address for reprints: Benjamin D. Kozower, MD, MPH, 660 S Euclid Ave, Campus Box 8234, St Louis, MO \\ 63110 (E-mail: kozowerb@wustl.edu). \\ J Thorac Cardiovasc Surg 2019;158:1230-1 \\ $0022-5223 / \$ 36.00$ \\ Copyright (c) 2019 by The American Association for Thoracic Surgery \\ https://doi.org/10.1016/j.jtcvs.2019.05.015
}

In this issue of the Journal, Osarogiagbon and colleagues ${ }^{1}$ report another outstanding study demonstrating that the vast majority of patients undergoing lung cancer resection do not receive any invasive mediastinal staging before surgery. ${ }^{1}$ Their results, which they derived from the MidSouth Quality of Surgical Resection Cohort between 2009 and 2018 , show that only $22 \%$ of patients had invasive nodal staging performed. The region of the United States captured by this cohort has one of the highest incidence rates of lung cancer in the country, and these results add to the growing evidence that we, the medical community, are not providing an adequate quality of surgical care.

Osarogiagbon and colleagues ${ }^{1}$ also defined a group of patients at high risk for nodal metastases by applying the criteria of tumor size of at least $3 \mathrm{~cm}$ or clinical nodepositive disease by computed tomographic or positron emission tomographic scan. Even in this group, unfortunately, the rate of invasive nodal staging was only $47 \%$. Not surprisingly, patients who did not receive preoperative nodal staging were also more likely to have no lymph nodes evaluated at the time of surgery, as documented by the pathology report. Furthermore, 20\% of these patients without preoperative nodal staging had no mediastinal nodes examined pathologically at any time during their care. These results should be alarming to the thoracic community.

In contrast to these results, The Society of Thoracic Surgeons General Thoracic Surgery Database recently demonstrated that their participants are adequately evaluating lymph nodes in the routine care of patients with lung cancer. $^{2}$ Society of Thoracic Surgeons participants reported a median lymph node count of 10 nodes, with a median of 4 lymph node stations sampled. Only $5 \%$ of patients had no mediastinal lymph nodes evaluated, and $80 \%$ of those were wedge resections. It is imperative to understand that these results come from a very different surgeon and hospital population than those evaluated in the current study of Osarogiagbon and colleagues. ${ }^{1}$ The majority of Society of

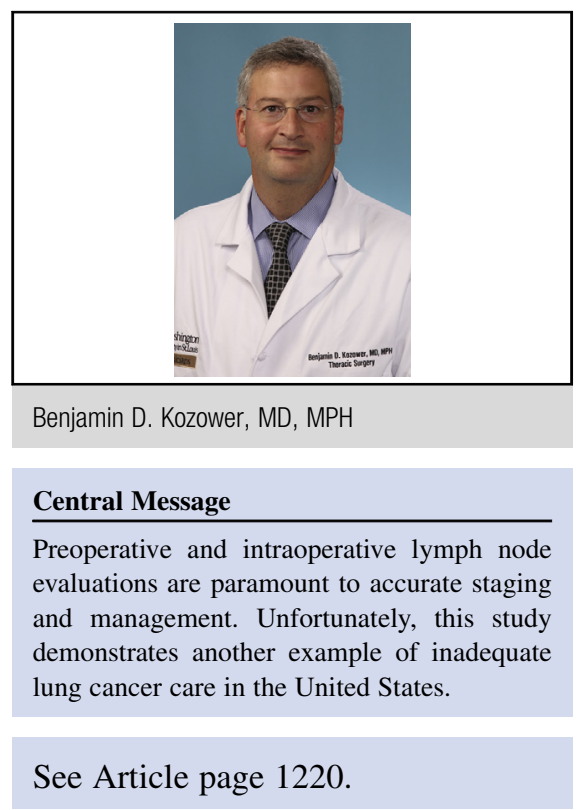

Thoracic Surgeons participants are dedicated thoracic surgeons who pay to participate in this specialty database, rather than a combination of thoracic, cardiac, and general surgeons in both academic and community practice from 4 contiguous regions of the mid-South.

Unfortunately, Osarogiagbon and colleagues ${ }^{1}$ provide yet another analysis demonstrating poor quality of lung cancer care within the United States. These results, which include hospitals performing at least 5 lung cancer resections, are in sharp contrast to those seen in the Canadian province of Ontario. In April 2007, Cancer Care Ontario regionalized lung cancer resection to hospitals performing 150 lung cancer resections per year, or a minimum of 50 resections per year in more remote areas. ${ }^{3}$ Their program has moved lung cancer resections to dedicated thoracic centers, such that small, inexperienced surgeons and hospitals rarely perform these procedures. The Ontario program has resulted in improved resource allocation, and long-term survival results are pending. The Canadian Health Care System is a single-payer system with its own advantages and disadvantages that are beyond the scope of this commentary. I believe, however, that policy and payer decisions demanding a minimum standard of process and outcome measures for lung cancer care will be required to effect substantive change within the United States. 


\section{References}

1. Osarogiagbon RU, Lee YS, Faris NR, Ray MA, Ojeabulu PO, Smeltzer MP. Invasive mediastinal staging for resected non-small cell lung cancer in a populationbased cohort. J Thorac Cardiovasc Surg. 2019;158:1220-9.e2.

2. Broderick SR, Grau-Sepulveda M, Kosinski AS, Kurlansky PA, Shahian DM, Jacobs JP, et al. STS composite score rating for pulmonary resection for lung cancer. Presented at: The Society of Thoracic Surgeons 55th Annual Meeting, San Diego, California; January 27-29, 2019. Ann Thorac Surg. 2019.

3. Bendzsak AM, Baxter NN, Darling GE, Austin PC, Urbach DR. Regionalization and outcomes of lung cancer surgery in Ontario, Canada. J Clin Oncol. 2017;35: 2772-80. 